\title{
Care coordination in Health Care for the child/adolescent in chronic condition
}

\author{
Coordenação do cuidado na Atenção à Saúde à(ao) criança/adolescente em condição crônica \\ Coordinación del cuidado en la Atención de Salud al niño/adolescente en condición crónica
}

\author{
Elenice Maria Cecchetti Vaz', Neusa Collet', Emília Gallindo Cursino", Franklin Dellano Soares Forte', \\ Rafaella Karolina Bezerra Pedrosa Magalhães', Altamira Pereira da Silva Reichert' \\ ' Universidade Federal da Paraíba. João Pessoa, Paraíba, Brazil. \\ "Universidade Federal Fluminense, Aurora de Afonso Costa Nursing School. Niterói, Rio de Janeiro, Brazil.
}

How to cite this article:

Vaz EMC, Collet N, Cursino EG, Forte FDS, Magalhães RKBP, Reichert APS. Care coordination in Health Care for the child/ adolescent in chronic condition. Rev Bras Enferm [Internet]. 2018;71(Suppl 6):2612-9. [Thematic Issue: Good practices in the care process as the centrality of the Nursing] DOI: http://dx.doi.org/10.1590/0034-7167-2017-0787

\section{Submission: 10-09-2017_Approval: 02-06-2018}

\section{ABSTRACT}

Objective: To analyze the care coordination for the child and adolescent in chronic condition and users planning in the Health Care Network. Method: Qualitative study, conducted with 26 health professionals and managers through Focus Groups. Thematic content analysis was used. Results: Care coordination is fragile, with lack of support from the management, and presence of high turnover of managers and professionals. The limits in the network planning are due to frequent changes in the careflow. Communication between levels of care and lack of counter-referral makes network care unfeasible. Final considerations: There is a need for planning in the Health Care Network and establishment of careflow, as well as the construction of communication channels and tools of referral and counterreferral between professionals and services, for the constitution and integration of the network from the perspective of user-centered care. Descriptors: Primary Health Care; Family Health Strategy; Chronic Disease; Child; Adolescent.

\section{RESUMO}

Objetivo: analisar a coordenação do cuidado à criança e ao adolescente em condição crônica e o ordenamento desses usuários na Rede de Atenção à Saúde. Método: Estudo qualitativo, realizado com 26 profissionais de saúde e gestores por meio de grupos focais. Utilizou-se a análise temática de conteúdo. Resultados: A coordenação do cuidado encontra-se frágil, com falta de apoio da gestão, e presença de alta rotatividade dos gestores e profissionais. Os limites no ordenamento da rede decorrem de mudanças frequentes no fluxo de atendimento. A comunicação entre os níveis de atenção e a falta de contrarreferência inviabiliza o cuidado em rede. Considerações finais: Há necessidade de ordenamento da Rede de Atenção à Saúde e estabelecimento de fluxo de atendimento, bem como a construção de canais de comunicação e instrumentos de referência e contrarreferência entre os profissionais e serviços, para constituição e integração da rede na perspectiva do cuidado centrado no usuário.

Descritores: Atenção Primária à Saúde; Estratégia Saúde da Família; Doença Crônica; Criança; Adolescente.

\section{RESUMEN}

Objetivo: analizar la coordinación del cuidado al niño y al adolescente en condición crónica y el ordenamiento de esos usuarios en la Red de Atención de Salud. Método: Estudio cualitativo, realizado con 26 profesionales de salud y gestores por medio de grupos focales. Se utilizó el análisis temático de contenido. Resultados: La coordinación del cuidado se encuentra frágil, con falta de apoyo de la gestión, y presencia de alta rotatividad de los gestores y profesionales. Los límites en el ordenamiento de la red proceden de cambios frecuentes en el flujo de atención. La comunicación entre los niveles de atención y la falta de contrarreferencia inviabiliza el cuidado en red. Consideraciones finales: Es necesario ordenar la Red de Atención de Salud y establecer el flujo de atención, así como la construcción de canales de comunicación e instrumentos de referencia y contrarreferencia entre los profesionales y servicios, para la constitución e integración de la red en la perspectiva del cuidado centrado en el usuario.

Descriptores: Atención Primaria de Salud; Estrategia de Salud Familiar; Enfermedad Crónica; Infantil; Adolescente. 


\section{INTRODUCTION}

Health Care Networks (RAS) have the purpose of guaranteeing the provision of continuous and comprehensive care for a given population ${ }^{(1)}$. In these networks, it is expected that the Family Health Strategy (FHS), adopted as the guiding principle of the Primary Health Care organization in Brazil's public health system, will be a provider of care and care coordination ${ }^{(2)}$. The RAS, with these characteristics, is expected to offer better quality actions and services, which generate better health indicators in multiple realities and positively impact the health of the population $^{(3)}$, especially children and adolescents, subjects of this study.

Thus, PHC has been considered central to chronic condition coordination in childhood and adolescence, which has been increasing considerably due to the demographic and epidemiological transitions.

In Brazil, the National Household Sample Survey ${ }^{(4)}$ revealed that $9.05 \%$ of children 0 to 4 years old; $9.73 \%$ of children/adolescents aged 5 to 13 years and $11.0 \%$ of adolescents aged 14 to 19 years of the total population in this age group have chronic disease. In the United States of America, a survey ${ }^{(5)}$ conducted covering the age group between 0 and 17 years showed that $13.44 \%$ had a chronic health condition and $9.90 \%$ had two or more.

This population usually accesses the points of the Care Network more frequently; has contact with different professional categories; and may be a beneficiary of ongoing health promotion and prevention actions $s^{(3,6)}$. This setting requires strong and robust PHC, capable of managing care at the right time and place, and planning the RAS of the child and adolescent in chronic condition.

Coordination connotes the ability to ensure the continuity of care, through the health team, with the recognition of problems that require constant follow-up and articulate with the function of the communication center of the $\operatorname{RAS}^{(7-8)}$.

In this context, health services have presented weaknesses in care coordination that result in interruption of flows, poor use of resources, and imbalance between demand and supply. This lack of care coordination is a result of the fragmentation of the health system that structures the multiple points of attention in silos that do not communicate and of the growth of people in chronic conditions ${ }^{(8)}$.

A study ${ }^{(9)}$ highlights the weaknesses of $\mathrm{PHC}$ in assuming the role of care coordination, as it does not bring together material (technological, operational, organizational) and symbolic (values, meanings and representations) conditions to hold the central coordination position of thematic health networks. Just as there is no RAS without robust PHC capable of coordinating care, $\mathrm{PHC}$ cannot play its role without a link between the three levels of care $^{(3)}$.

A study ${ }^{(10)}$ that addressed care coordination from the perspective of the parents of children with special needs, showed that deficiency in communication and coordination of the health system, normally results in the lack of accessible and consolidated information about the child's condition. Another study ${ }^{(11)}$ pointed out that the fragility in the communication and the non-integration of the services constituting the RAS make it difficult to manage care by the FHS.
As a result, improved coordination of health care has become a priority for health systems worldwide. Studying care coordination for children and adolescents in chronic condition is fundamental, considering that this group needs to be attended by different health professionals and, in times of transition of care, between different health services ${ }^{(8)}$. In addition, they need care in a timely manner and cannot be without Primary Care support ${ }^{(11)}$.

\section{OBJECTIVE}

To analyze the care coordination of child and adolescent in chronic condition and the planning of Health Care Network users.

\section{METHOD}

\section{Ethical aspects}

The study respected the formal requirements of the regulatory national and international rules research involving human beings. The research was approved by the Research Ethics Committee of the Health Sciences Center of the Universidade Federal da Paraíba and was authorized by an Agreement of Consent by the Municipal Office Health and the district directors of the municipality in question. The Informed Consent Form was read and signed by the participants.

\section{Type of study}

This is a descriptive-exploratory study, with a qualitative approach and with theoretical support in Mendes. According to this author, Primary Health Care, in order to establish itself as a strategy for the organization of the Unified Health System (SUS- Sistema Único de Saúde), in the perspective of Health Care Networks, has to have a problem-solving function; the function of care manager, and flows and counterflows planner of users, products and information throughout the RAS; and the health responsibility function of the population assigned to the Family Health Strategy ${ }^{(2)}$.

\section{Methodological procedures}

\section{Setting and study participants}

The survey was conducted in João Pessoa-PB, a city in northeastern Brazil, with 742,478 inhabitants and coverage of $86.89 \%$ of the Family Health Strategy (FHS), and $100 \%$ coverage of Community Health Agents (CHA) and 181 Oral Health Teams (OHT). The municipality is organized, in health, from the perspective of five Health Districts (HD). A study carried out in the context of the Family Health Units (FHU) of the city of João Pessoa-PB with 26 Primary Care professionals, of whom 11 were managers (one PHC manager, four HD directors and six matrix sponsors), four were doctors and 11 were nurses who shared responsibility for the care for the child/adolescent/family in chronic condition attended to in the FHU of that municipality.

\section{Collection and data organization}

The FHU selection process was started with a total of 191 FHU units, with representatives from each of the five health districts in the city under study, in order to identify teams that would serve children and adolescents in chronic conditions. If 
the unit drawn did not serve this clientele, another draw would be carried out, and so on. At the end of this stage, a list of 20 FHU was generated, totaling 42 Family Health Teams (FHT) that became part of this research.

For the data collection technique, we chose the Focus Group, because the participants can interact with each other. Focus Group $^{(12)}(\mathrm{FG})$ is defined as a meeting for discussion, reflection and dialogue on a given theme facilitated by a moderator. After contacts with representatives of the Municipal Office Health $(\mathrm{MOH})$ of $\mathrm{HD}$ and $\mathrm{FHU}, 89$ professionals were invited among doctors, nurses and managers in the recruitment process for the FG, who met the criteria for inclusion: working at the FHS for over a year and have experience of caring for children/ adolescents/families in chronic condition in their daily lives at FHU; and to be the coordinator of Primary Health Care and Health Care for Children and Adolescents in the $\mathrm{MOH}$, to be technical director of the HD and matrix supporters of the FHT. We excluded managers, physicians and nurses who were on leave or vacations during the period of data collection.

Focus Groups were previously scheduled, according to availability and organization of the teams. Five FG were performed between June and July 2016, with up to 7 participants per group, totalizing 26 participants, four of them with medical professionals, nurses and matrix supporters, and one with managers and technical directors. The implementation of the FG was supported by a moderator and two observers. The meetings lasted approximately 90 minutes and were held in a Higher Education institution, with privacy and conditions to comfortably welcome the participants. Only the FG of managers occurred in a private room of $\mathrm{MOH}$, due to their preference. It was read a text about the topic of study and generating questions: How has the coordination of child/ adolescent/family care in chronic condition in the Family Health Strategy in the municipality of João Pessoa been conducted? How do you perceive the Health Care Network in child/adolescent/ family care in chronic condition? What challenges do you face in managing child/adolescent/family care in chronic condition? How do activities of the Family Health Teams and managers of Primary Health Care integrate the Health Care Network in the care for the child/adolescent/family in chronic condition?

FG moments were recorded and later transcribed for analysis. For reasons of ethics, the transcribed lines were de-identified, avoiding possible elements of identification of the participants. By means of a procedural analysis of the data, it was considered that the number of professionals and managers involved was sufficient the recidivism and saturation ${ }^{(13)}$ of information, in such a way, reaching the proposed objectives and research object understanding and contextualization.

Participants were identified by order of Focus Groups (FG1, FG2, FG3, FG4 and FGG).

\section{Data analysis}

The empirical material derived from the focus groups was submitted to the Content Analysis (CA) technique in thematic modality ${ }^{(14)}$. The analytical procedure followed three chronological periods: pre-analysis with floating reading to know the initial ideas of the texts and make cuts about care coordination and planning of the RAS of the child/adolescent in chronic condition for corpus constitution; exploration of the material by exhaustive and comprehensive reading with the primary coding of the speeches, in order to identify the perception of the FHT professionals and PHC managers on the object of study; and inference/treatment of the results obtained and their interpretation/signification ${ }^{(14)}$, discussing them in the light of the study's theoretical framework ${ }^{(2)}$.

\section{RESULTS}

\section{Participants characterization}

From the twenty-six participants, two were male and twentyfour female, with ages ranging from 25 to 65 years. The training time ranged from two to thirty-eight years. With the exception of a single participant, the others had at least one latu sensu specialization in health. The duration of the FHS ranged from one to eighteen years.

From the data coding, the thematic axis ${ }^{(14)}$ was built "the perception of professionals and managers about the care coordination and planning of the Health Care Network of children and adolescents in chronic condition". This analysis was carried out in two dimensions, taking into account the two aspects of coordination, namely the integration of care and communication in the network.

\section{(Dis)Integration of child and adolescent care in chronic condition in the Health Care Network}

This first dimension shows how professionals and managers perceive the integration of care in the course of the child and the adolescent's pathway with chronic disease and their family through the Health Care Network. For them, the care coordination for the child and the adolescent in these conditions is directly related to the weaknesses of the network, which may interfere with the comprehensiveness of care.

\begin{abstract}
The network is pretty poor. Most of the time we cannot make appointments with experts. Comprehensiveness and equity don't happen. (FG3)
\end{abstract}

We have nowhere to send their demand. We perceive certain fragility in the network. We would need some form of a more consistent network. (FG2)

It is the role of the PHC to coordinate care for the child, the adolescent and their family in chronic condition. However, in the view of the study participants, when there is no solution in the other levels of care, the PHC is not able to solve the problem and, therefore, faces difficulty in coordinating in order to solve health needs of these users.

We serve the patient, but when you need to go to a secondary or tertiary stage, existing limitations in services begin. You cannot find the support you need. The patient doesn't have his/her problem solved. There is lack of solution. (FG1)

The patient returns to us with the same problem. It isn't decisive. And for the child and adolescent in chronic condition, there is no solution at all. (FG4) 
This fragility of the network was attributed to the lack of management support for the resolution of child and adolescent care in chronic condition and to their family.

The cases go to the support [matrix] to try to solve in the health district. It is a matter of priority for management. There is lack of management involvement in child care. (FG1)

Another factor that weakens the network, from the point of view of FHT professionals, is the turnover of managers and professionals in the three levels of care due to the lack of job stability. And this directly reflects on the continuity of care.

Professionals' turnover is very large in services. Who is going to give continuity, if is changing? If the network were good, we wouldn't be distressed [PHC] because we would already know the right professional to refer you. (FG1)

Employment relationship is precarious, so it changes manager, NASF [Family Health Support Nucleus], coordination. When the supporter is starting to engage, you gotta go to another unit. (FG4)

It was also evidenced that there is no RAS planning for this specific group, since managers and health professionals are unaware of the careflow.

There is a lack of planning for the professional to know who to look for to try to solve the child's problem. In [federal] hospital X has professionals that address this issue of chronic diseases. I'm not sure if it still going on. But, we had this articulation. (FGG)

There is no planning. There is no network. The net is stuck at various points and full of knots. When we take the child in chronic condition and forward to the [community] Y hospital, they say it is to the [state] hospital Z. (GF4)

Continuous changes in the careflow are factors that also interfere in the planning of this network.

Suddenly it was a way for you to send to that particular location on the network. Shortly thereafter, the flow has changed. There is no correct flow. (FG1)

The flows are not well defined, at least clear knowledge of who is there [PHC]. We have a lot of difficulty. (FG2)

Fragility of the communication in the care network in the care for the child and the adolescent in chronic condition

This dimension addresses how study participants perceive communication between the FHS and specialized and hospital services, and what this may interfere in the care coordination to this group, as well as in the arrangement of those by RAS. They highlight the lack of communication between professionals at three levels of care, as well as with managers.

Network professionals don't communicate with each other. Professionals of the same service don't know what others do. Even management professionals don't communicate with each other. (FG3)
There is lack of communication among network professionals. There is lack of connectivity between services, managers and professionals. There is no sharing. (FG2)

Another factor that directly interferes in the care coordination is related to the PHC referral form fills and the counter-referral for the services of the specialized and hospital networks. Because they are considered a form of communication between the three levels of care, the gaps in this process make it difficult to follow these users in the network.

It is the responsibility of network professionals to carry out referral and counter-referral. It isn't appropriate for the network to have the door open for the specialty, if professionals don't issue the counter-referral so that the FHS, who follows up the child or adolescent, can continue the treatment. (FGG)

We can't get information from other levels of care. Counterreferral doesn't happen. If the patient returns with the counterreferral, we can continue the case. (FG1)

Some professionals explain that, in a few situations, they received the written counter-referral and filled out by the professional services available on the network for the care for the child and the adolescent in chronic condition. However, as it is not a common practice, it generates strangeness among FHT professionals.

The colleague from the [community] $Y$ hospital recorded everything he did in the counter-referral. We're not used to it. It is a rarity, but it is possible. (FG2)

I have already received a well-explained counter-referral from [federal] hospital X. Everything came out well detailed in the child's discharge summary. (FG4)

\section{DISCUSSION}

The care coordination of children and adolescents in chronic condition is a complex process that must be effective to be problem solving, so that continuity of care in different levels of care is guaranteed. It presupposes an organization of health care centered on the sick child and the adolescent or the family in chronic situation, in the perspective of the continuity of the health actions, considering the different points of RAS, which are organized to integrate and improve the actions and the health services committed to the quality of care anchored in the principle of comprehensiveness to ensure that users receive the care they need ${ }^{(15)}$. Therefore, the Primary Care provider must be able to integrate all the care that the user receives through coordination between services ${ }^{(16)}$.

The lack of care coordination is one of the main problems of fragmented health systems and greatly affects children and adolescents with chronic diseases. It manifests itself through a set of frequent situations, highlighting: the lack of communication between the $\mathrm{PHC}$ and the specialized services; the lack of continuity of assistance; and the lack of an identifiable point of attention and with coordinating responsibility in the perspective of users and their families ${ }^{(8)}$. 
In the perception of the professionals and managers, the RAS of the child and the adolescent in chronic condition in the studied municipality, is fragile and deficient, not being wholeness or equity. They suggest that there is a need to strengthen this network, making it more consistent, integrated and effective.

A study ${ }^{(17)}$ carried out with families of children attending the Emergency Medical Units of Cascavel-PR corroborates these results when affirming that there is fragility of coordination in $\mathrm{PHC}$ and that this repercussions in non-resoluteness in the Health Care for the child in chronic condition.

Contrasting this aspect, research ${ }^{(18)}$ that evaluated the coordination attribute in the FHS in the municipality of Colombo-PR, showed that it is possible to integrate care, provided that the units are articulated with the specialty services.

The integration of care is one of the challenges of building a universal and equitable health model. The legitimacy of producing comprehensive care is a fundamental mechanism to strengthen universality and equity in the health system ${ }^{(19)}$.

Regarding the care for the child and the adolescent in chronic condition, provided in the PHC of the municipality in focus, limitations were identified when the FHT need to be referred to other points of attention. The professionals perceive that the lack of management support interferes in the quality of care at the secondary and tertiary levels, since they are not very resolvable. This fragility of RAS hinders the continuity of PHC care. This is of fundamental importance because it has the potential to minimize errors and improve user safety ${ }^{(20)}$.

On the other hand, when the manager facilitates access to information, as well as communication and coordination among health professionals and users, it improves access to health services and the relationship of trust, with positive repercussions in decision making ${ }^{(21)}$.

The fragility in the employment bond proved to be an aspect that hinders the integration of care. The turnover of managers and health professionals in the three levels of care weakens the potential of RAS, affecting the (dis)continuity of care.

Research ${ }^{(22)}$ corroborates these results by highlighting that the high turnover of professionals in Primary Health Care (PHC) may be related to the precarious bond in the hiring, and may interfere in the quality of the care provided. A study ${ }^{(23)}$ carried out in Montes Claros-MG evidenced instability in the employment relationship of FHS professionals, where $96.7 \%$ were hired employees and $3.3 \%$ of the effective staff. He also pointed out that the high turnover and the low availability of professionals to the demands of the PHC can compromise the RAS management planning and quality of care.

A research ${ }^{(24)}$ pointed out that when health professionals present low turnover, that is, they are maintained for a longer period of time, there is a prolonged follow-up of the users, which seems to contribute to the strengthening of user-familyprofessional relations. On the other hand, it is important to reflect on the work process in health in each point of RAS, favoring humanized, comprehensive and problem-solving care.

This turnover does not happen only in the primary level of Health Care, because a study ${ }^{(25)}$ carried out in Montes ClarosMG, evidenced the turnover of professionals and insufficient specialists in the emergency and emergency services.
Considering the personnel management policy of the SUS, several mechanisms for incorporating personnel and contracting modalities have been used, with a view to offering faster responses to the demands of the services. However, contract professionals do not create strong ties or bonds, which make them more easily able to change jobs. This implies problems for the quality of the assistance and, consequently, the difficulty of the managers in maintaining a cohesive and fixed team at the front of the service ${ }^{(26)}$.

The study participants report that there is no network planning, reporting that there is no defined careflow for the child and adolescent in chronic condition, which interferes with the non-resolving of the health needs of these users. This lack of definition is directly related to the frequent changes in this flow, causing them to ignore the correct way to refer them to other services and leave the professionals and users lost and loose in the Health Care Network.

Thus, sick children and adolescents, and family in chronic disease build, create, invent their own networks, seeking the resolution of their health problems that relieve them of suffering and pain ${ }^{(27)}$. This study confirms that some patients with complex chronic conditions and multi-morbidity may be unable to obtain the continuity they need and highlights the potential for continuity of the relationship to help prevent vulnerable patients from falling into care gaps ${ }^{(28)}$.

This situation is contrary to what is recommended for Primary Care, since this level of care should be able to solve more than $90 \%$ of the population's health problems and to pan the flows and counterflows of people, products and information throughout the service network ${ }^{(2,8)}$.

When flows are defined and guide care, they contribute to the proper targeting of users within RAS. However, when there is difficulty in integrating services, completeness is not consolidated $^{(29)}$.

Corroborating the results of this study, a study ${ }^{(30)}$ carried out in Belo Horizonte-MG found that there is no defined flow for the referrals of children in chronic condition, emphasizing that Primary Care in the service network must capture this population, coordinate and articulate the different care required in the course of the three levels of care.

The integration between services is essential and it is up to the managers of the health services to plan, according to the reality of each municipality, the flows in the network for the proper referrals. In this study, it was identified that even the managers do not have clarity regarding referral services for children in chronic conditions. In addition, there is no articulation between the points of attention of the RAS, evidencing that the careflows for the child and adolescent in chronic condition in the municipality in question, occurs in a disordered way.

In addition to actions that integrate services and care for the child and adolescent population in chronic condition, in order for PHC to effectively assume its role of care coordination, it is also necessary to strengthen the information system between the different levels. This implies an effective communication, whose exchanges of information are complete and clear between services and health professionals $\mathrm{s}^{(8)}$.

The capacity of communication among the members of a team is fundamental to its good functioning, reverting in 
improving the quality of health services ${ }^{(31)}$. On the other hand, the lack of communication between professionals, services and families weakens coordination by PHC, as evidenced by the study ${ }^{(17)}$ conducted in Cascavel-PR.

The coordination of child and adolescent care in chronic condition and their family in the present study is fragile, since the participants report that there is no effective communication between the three levels of care. They observe that the professionals of the same team do not communicate with each other, or with other members of the FHT, nor with the professionals of other services nor with the managers.

In this way, it is understood that the establishment of careflows is not enough; it is also a very important element the communication between managers and workers within the RAS. In this direction, open communication between the RAS professionals facilitates decision making, as well as the exchange of professional expertise, anchored in respect for users, to guarantee the comprehensiveness of care.

These results are also consistent with the research ${ }^{(32-33)}$ car- $^{-}$ ried out in Italy, which showed that lack of communication among team members can lead to discontinuity of care for children with special health needs. This situation is worrying, since communication and the exchange of information represented critical functions of the system of interaction between family members and health teams, necessary for the construction of care projects, capable of integrating the different purposes of the work in the points that make up the RAS. Therefore, there is a need not only for the organization of communication between services, but also for the communication of professionals from the same team, from an interprofessional perspective ${ }^{(34)}$.

Communication gaps between $\mathrm{PHC}$ and other health care points make it difficult to provide adequate care for children, adolescents in chronic conditions and their families, but also does not allow for correct planning of referrals to outpatient and hospital care, as expected from an efficient referral and counterreferral service. It was evidenced that references are made by the FHT, however, most of the time these professionals do not receive counter-referrals from experts or from hospitals. When the population returns to Primary Care without the counterreferral, it becomes a hindrance to care management.

On the other hand, in relation to counter-referral receiving, some participants mention that they have already received these forms filled in correctly and in detail by the professional of the outpatient and hospital services. However, what is seen in the speeches is surprising with this attitude despite the obligation of the user to return to the FHS with the counter-referral.

Confirming these findings, a study ${ }^{(16)}$ states that although the health model established in the PHC guidelines is geared towards comprehensive health care for children, issues such as counter-referral and communication between the three levels of care need to be more valued by health professionals network.

\section{Study limitations}

The limitations of the study are related to the quantitative of FHU listed and the non-participation of all professionals and managers invited to the Focus Groups. Considering that the present research occurred in a certain setting, with a group of SUS workers and managers, it would be interesting that other types of studies with other data collection tools could be performed. The objective is the qualified, problem-solving and comprehensive care for this part of the population that requires singular care.

\section{Contributions to the Nurse, Health or Public Policy}

The participants' perceptions of the study on the care coordination of child and adolescent in chronic condition not only add important understanding of the system, but also health condition of this specific population. The reality presented enables Primary Care physicians and nurses and health managers to organize their work process, flows and itineraries in the perspective of comprehensive health care, valuing users and their needs as a central element of Health Care Networks for the strengthening and consolidation of SUS.

\section{FINAL CONSIDERATIONS}

The results show that the Health Care Network in the city studied has important gaps and requires greater articulation among primary, outpatient and hospital professionals, as well as professionals trained to deal with the chronic health conditions of the child and adolescent population. They highlight the (dis) integration of the care and weaknesses in communication that undermine coordination and planning by the FHS.

They also point to the lack of a consistent network, lack of planning of children and adolescents in chronic conditions and absence of a defined flow for these users. It was also observed that the few and sporadic actions performed to this population do not have sustainability to offer problem solving to the singular and continuous demands necessary for the care.

This problem requires a closer look of the managers and health professionals in the sense of thinking about strategic actions considered fundamental for the follow-up of these users by RAS, among them: implantation of electronic medical records; organization of operating groups for this specific demand; creation of reference centers in Health Districts; increase of active searches and home visits to children and adolescents with chronic condition; formalization of the referral system and counter-referral; identification of these groups in information systems; discussion of health indicators. In addition, to make this network more consistent, it is imperative to define flow and counterflow for these users.

Finally, there is a need for studies that seek to assess the care coordination of child and adolescent in chronic condition in other Brazilian realities, to deepen the knowledge about the subject and to identify fragile points of the network, in order to contribute for the Primary Care to assume and fulfill its role of planning the users' Network of Health Care.

\section{FUNDING}

This research was supported by the National Council for Scientific and Technological Development (CNPq), Process 474762/2013-0. 


\section{REFERENCES}

1. Brasil. Ministério da Saúde. Portaria n. 4.279, de 30 de dezembro de 2010. Estabelece diretrizes para a organização da Rede de Atenção à Saúde no âmbito do Sistema Único de Saúde (SUS). Diário Oficial da União[Internet]. 31 de dezembro de 2010 [cited 2017 Jul 14];Seção 1:88. Available from: http://bvsms.saude.gov.br/bvs/saudelegis/gm/2010/anexos/anexos_prt4279_30_12_2010.pdf

2. Mendes EV. A construção social da Atenção Primária à Saúde. Brasília: Conselho Nacional de Secretários de Saúde; 2015.

3. Bousquat A, Giovanella L, Campos SEM, Almeida PF, Martins CL, Mota PHS, et al. Primary Health Care and the coordination of care in health regions: managers' and users' perspective. Ciênc Saúde Colet[Internet]. 2017[cited 2017 Jul 14];22(4):1141-54. Available from: http://www.scielo.br/pdf/csc/v22n4/en_1413-8123-csc-22-04-1141.pdf

4. Brasil. Instituto Brasileiro de Geografia e Estatística-IBGE. Pesquisa Nacional por Amostra de Domicílios: um panorama da saúde no Brasil, acesso e utilização dos serviços, condições de saúde e fatores de risco e proteção à saúde, 2008. Rio de Janeiro: IBGE; 2010.

5. National Survey of Children's Health. Child and Adolescent Health Measurement Initiative (CAHMI), "2011-2012 NSCH: Child Health Indicator and Subgroups SAS Codebook, Version 1.0" 2013[Internet]. Maryland; 2013[cited 2017 Jul 07]. Available from: http://childhealthdata.org/docs/nsch-docs/sas-codebook_-2011-2012-nsch-v1_05-10-13.pdf

6. Cady R, Looman W, Lindeke L, LaPlante B, Lundeen B, Seeley A, et al. Pediatric Care coordination: lessons learned and future priorities. Online J Issues Nurs[Internet]. 2015[cited 2017 Jun 26];20(3). Available from: http://www.nursingworld.org/MainMenuCategories/ ANAMarketplace/ANAPeriodicals/OJIN/TableofContents/Vol-20-2015/No3-Sept-2015/Pediatric-Care-Coordination.html

7. Starfield B. Atenção primária: equilíbrio entre necessidades de saúde, serviços e tecnologia. Brasília: UNESCO; 2002.

8. Mendes EV. O acesso à Atenção Primária à Saúde. Brasília: CONASS; 2017.

9. Cecílio LCO, Andreazza R, Carapinheiro G, Araújo EC, Oliveira LA, Andrade MGG, et al. A Atenção Básica à Saúde e a construção das redes temáticas de saúde: qual pode ser o seu papel? Ciênc Saúde Colet[Internet]. 2012[cited 2017 Aug 08];17(11):2893-902. Available from: http://www.scielo.br/pdf/csc/v17n11/v17n11a05.pdf

10. Cady RG, Belew JL. Parent perspective on care coordination services for their child with medical complexity. Children[Internet]. 2017[cited 2017 Jun 26];4(6):45. Available from: https://www.ncbi.nlm.nih.gov/pmc/articles/PMC5483620/

11. Nóbrega VM, Silva MEA, Fernandes LTB, Viera CS, Reichert APS, Collet N. Chronic disease in childhood and adolescence: continuity of care in the Health Care Network. Rev Esc Enferm USP[Internet]. 2017[cited 2017 Aug 16];51:e03226. Available from: http:// dx.doi.org/10.1590/s1980-220x2016042503226

12. Stewart DW, Shamdasani PN. Focus groups: theory and practice applied social research methods series. 3 ed. California: Sage; 2015.

13. Minayo MCS. Amostragem e saturação em pesquisa qualitativa: consensos e controvérsias. Rev Pesqui Qualit[Internet]. 2017[cited 2017 Aug 21];5(7):1-12. Available from: https://editora.sepq.org.br/index.php/rpq/article/view/82/59

14. Bardin L. Análise de conteúdo. São Paulo: Edições 70; 2012.

15. Magalhães Jr HM, Hêider AP. Atenção básica enquanto ordenadora da rede e coordenadora do cuidado: ainda uma utopia? Saúde Debate[Internet]. 2014[cited 2017 Aug 08];(51):14-29. Available from: http://cebes.org.br/site/wp-content/uploads/2014/12/ Divulgacao-51.pdf

16. Silva SA, Fracolli LI. Evaluating child care in the Family Health Strategy. Rev Bras Enferm[Internet]. 2016[cited 2017 Jul 21];69(1):4753. Available from: http://dx.doi.org/10.1590/0034-7167.2016690107i

17. Silva RMM, Silva Sobrinho RAS, Neves ET, Toso BRGO, Viera CS. Challenges in the coordination of children's healthcare. Ciênc Saúde Colet[Internet]. 2015[cited 2017 Jul 21];20(4):1217-24. Available from: http://www.scielo.br/pdf/csc/v20n4/1413-8123csc-20-04-01217.pdf

18. Oliveira VBCA, Veríssimo MLOR. Children's health care assistance according to their families: a comparison between models of Primary Care. Rev Esc Enferm USP[Internet]. 2015[cited 2017 Jul 15];49(1):30-6. Available from: http://www.scielo.br/pdf/reeusp/ v49n1/0080-6234-reusp-49-01-0030.pdf

19. Assis MMA, Nascimento MAA, Pereira MJB, Cerqueira EM. Comprehensive health care: dilemmas and challenges in nursing. Rev Bras Enferm[Internet]. 2015[cited 2017 Jul 15];68(2):333-8. Available from: http://www.scielo.br/pdf/reben/v68n2/en_0034-7167reben-68-02-0333.pdf

20. Davis K, Stremikis K, Squires D, Schoen C. Mirror, mirror on the wall. How the performance of the U.S. Health Care System compares internationally[Internet]. 2014[cited 2017 Aug 08]. New York: The Commonwealth Fund. Available from: http://www. resbr.net.br/wp-content/uploads/historico/Espelhoespelhomeu.pdf

21. Hudon C, Chouinard MC, Diadiou F, Lambert M, Bouliane D. Case management in primary care for frequent users of health care services with chronic diseases: a qualitative study of patient and family experience. Ann Fam Med[Internet]. 2015 [cited 2017 Jun 26];13(6):523-8. Available from: http://www.annfammed.org/content/13/6/523.full

22. Mayer BLD, Huppes RE, Silva FS, Weiller TH, Poll MA. Profissionais de saúde da atenção básica e a avaliação: revisão integrativa da literatura. Saúde[Internet]. 2015[cited 2017 Jul 25];41(1):19-28. Available from: https://periodicos.ufsm.br/revistasaude/article/ viewFile/9209/pdf 
23. Gonçalves CR, Cruz MT, Oliveira MP, Morais AJD, Moreira KS, Rodrigues CAQ, et al. Recursos humanos: fator crítico para as redes de atenção à saúde. Saúde Debate[Internet]. 2014[cited 2017 Jul 25];38(100):26-34. Available from: http://www.scielo.br/ $\mathrm{pdf} / \mathrm{sdeb/v38n100/0103-1104-sdeb-38-100-0026.pdf}$

24. Soares JL, Araújo LFS, Bellato R, Petean E. Tecitura do vínculo em saúde na situação familiar de adoecimento crônico. Interface[Internet]. 2016[cited 2017 Jul 21];20(59):929-40. Available from: http://www.scielo.br/pdf/icse/v20n59/1807-5762-icse-1807-576220150944.pdf

25. Torres SFS, Belisário AS, Melo EM. A Rede de Urgência e Emergência da Macrorregião Norte de Minas Gerais: um estudo de caso. Saúde Soc[Internet]. 2015[cited 207 Jul 25];24(1):361-73. Available from: http://www.scielo.br/pdf/sausoc/v24n1/01041290-sausoc-24-1-0361.pdf

26. Randown RMV, Brito MJM, Caram CS, Rezende LC, Caçador BS, Montenegro LC. Práticas gerenciais em unidades de pronto atendimento no contexto das redes de atenção à saúde. RAS[Internet]. 2014[cited 2017 Jul 25];16(64):79-88. Available from: http://hdl.handle.net/1843/GCPA-8UQGHC

27. Tarrant C, Windridge K, Baker R, Freeman G, Boulton M. 'Falling through gaps': primary care patients' accounts of breakdowns in experienced continuity of care. Fam Pract[Internet]. 2015[cited 2017 Jul 25];32(1):82-7. Available from: https://academic.oup. com/fampra/article/32/1/82/2964809/Falling-through-gaps-primary-care-patients

28. Waibel S, Henao D, Aller MB, Vargas I, Vázquez ML. What do we know about patients' perceptions of continuity of care? a metasynthesis of qualitative studies. Int J Qual Health Care[Internet]. 2012[cited 2017 Aug 08];24(1):39-48. Available from: https://doi. org/10.1093/intqhc/mzr068

29. Sousa SM, Bernardino E, Crozeta K, Peres AM, Lacerda MR. Integrality of care: challenges for the nurse practice. Rev Bras Enferm[Internet]. 2017[cited 2017 Aug 08];70(3):504-10. Available from: http://dx.doi.org/10.1590/0034-7167-2016-0380

30. Duarte ED, Silva KL, Tavares TS, Nishimoto CLJ, Silva PM, Sena RR. Care of children with a chronic condition in primary care: challenges to the healthcare model. Texto Contexto Enferm[Internet]. 2015[cited 2017 Jul 15];24(4):1009-17. Available from: http:// www.scielo.br/pdf/tce/v24n4/0104-0707-tce-24-04-01009.pdf

31. Lapão LV, Arcêncio RA, Popolin MP, Rodrigues LBB. The role of Primary Healthcare in the coordination of Health Care Networks in Rio de Janeiro, Brazil, and Lisbon Region, Portugal. Ciênc Saúde Colet[Internet]. 2017[cited 2017 Jul 15];22(3):713-23. Available from: http://www.scielo.br/pdf/csc/v22n3/en_1413-8123-csc-22-03-0713.pdf

32. Zanello E, Calugi S, Rucci P, Pieri G, Vandini S, Faldella G, et al. Continuity of care in children with special healthcare needs: a qualitative study of family's perspectives. Ital J Pediatr[Internet]. 2015[cited 2017 Aug 08];41:7. Available from: https://www.ncbi. nlm.nih.gov/pmc/articles/PMC4328636/

33. Zanello E, Calugi S, Sanders LM, Lenzi J, Faldella G, Rucci P, et al. Care coordination for children with special health care needs: a cohort study. Ital J Pediatr[Internet]. 2017[cited 2017 Aug 08];43:18. Available from: https://www.ncbi.nlm.nih.gov/pmc/articles/ PMC5347827/

34. Agreli HF, Peduzzi M, Silva MC. Patient centered care in interprofessional collaborative practice. Interface[Internet]. 2016[cited 2017 Aug 08];20(59):905-16. Available from: http://www.scielo.br/pdf/icse/v20n59/en_1807-5762-icse-1807-576220150511.pdf 